\title{
Celebrating the 70 years of pyridostigmine on therapy of Myasthenia Gravis: historical aspects of the preliminary trials
}

\author{
Celebrando os 70 anos da piridostigmina no tratamento da Miastenia Gravis: aspectos \\ históricos dos ensaios clínicos preliminares
}

Paulo José LORENZONI', Cláudia Suemi Kamoi KAY', Renata Dal-Prá DUCCI', Otto Jesus Hernandez FUSTES', Lineu Cesar WERNECK', Rosana Herminia SCOLA ${ }^{1}$

\begin{abstract}
Currently, pyridostigmine bromide is an indispensable anticholinesterase agent used worldwide to treat patients with Myasthenia Gravis (MG). However, pyridostigmine bromide was unsuccessful in its "pioneering trials" to treat a series of MG patients. There are important historical landmarks before pyridostigmine bromide becomes useful, safe and indispensable for MG therapy. After 70 years of these "pioneering trials", this article reviews some historical aspects related to them, as well as other preliminary trials using pyridostigmine bromide as therapy for MG patients.
\end{abstract}

Keywords: myasthenia gravis; pyridostigmine; treatment; history.

\section{RESUMO}

Atualmente, o brometo de piridostigmina é um indispensável agente anticolinesterásico usado em todo o mundo no tratamento de pacientes com Miastenia Gravis (MG). Contudo, o brometo de piridostigmina não foi bem-sucedido, em seus "ensaios clínicos pioneiros", no tratamento de uma série de pacientes com MG. Existem importantes marcos históricos antes do brometo de piridostigmina se tornar útil, seguro e indispensável no tratamento da MG. Após 70 anos desses "ensaios clínicos pioneiros", este artigo revisa alguns aspectos históricos a eles relacionados, bem como a outros estudos preliminares que usaram o brometo de piridostigmina como um tratamento para pacientes com MG.

Palavras-chave: miastenia gravis; piridostigmina; tratamento; história.

In the past, myasthenia gravis (MG) was considered a disease unresponsive to therapy and associated to high mortality rates. This situation began to change in 1934, when physostigmine was used by Mary Broadfoot Walker, as an anticholinesterase agent to MG treatment ${ }^{1-4}$. Since then, other drugs acting as anticholinesterase agents, analogues of physostigmine, were developed ${ }^{2-6}$. The first of them was neostigmine, which was the drug of choice to treat MG for years ${ }^{3-7}$. However, even though MG patients presented an effective response to neostigmine therapy, this anticholinesterase agent had some disadvantages when it was orally administrated ${ }^{5-8}$. In addition, neostigmine has a brief action and several autonomic side effects, despite of the use of atropine ${ }^{5-8}$. Thus, efforts to find a neostigmine analogue that would have a prolonged and favourable strengthening effects were put in, as well as no disagreeable gastrointestinal stimulation.

Pyridostigmine bromide, called Mestinon worldwide, was first synthesized by Urban and Schnider in the Hoffmann-La Roche Laboratories in Basel (Switzerland), in $1945^{9}$. Pyridostigmine bromide was released for preliminary trials,

${ }^{1}$ Universidade Federal do Paraná, Hospital de Clínicas, Departamento de Clínica Médica, Serviço de Neurologia, Serviço de Doenças Neuromusculares, Curitiba PR, Brazil.

Paulo José LORENZONI iD https://orcid.org/0000-0002-4457-7771; Cláudia Suemi Kamoi KAY iD https://orcid.org/0000-0003-0173-0809; Renata Dal-Prá DUCCI (ID) https://orcid.org/0000-0002-1673-5074; Otto Jesus Hernandez FUSTES (iD) https://orcid.org/0000-0003-0778-5376; Lineu Cesar WERNECK iD https://orcid.org/0000-0003-1921-1038; Rosana Herminia SCOLA iD https://orcid.org/0000-0002-3957-5317 Correspondence: Paulo José Lorenzoni; Serviço de Doenças Neuromusculares, Hospital de Clínicas da UFPR; Rua General Carneiro, 181 / $3^{\circ}$ andar; 80060-900 Curitiba PR, Brazil; E-mail: lorenzoni@ufpr.br 
also referred to by one or more of the following designations: $\mathrm{Nu}-5130, \mathrm{Nu}-1317$, prostigmin-5130, Ro-5130, Ro1-5130 and Ro2-1317 $7^{5-11}$. Initially, this compound was available in tablets of $30 \mathrm{mg}$, ampules of $25 \mathrm{mg}$, or 5 millilitres (mL) containing 1 or $2 \mathrm{mg} / \mathrm{mL}$, after dragees of $60 \mathrm{mg}$ were at hand ${ }^{3-11}$. This newest drug was offered by the Hoffmann-La Roche Laboratories to the centers, which treat MG patients, since late 1947.

There are few citations regarding the initial management of MG patients with pyridostigmine. However, there are citations of "pioneering trials" to treating MG patients with pyridostigmine, which occurred in 1947 and 1948 5 .

In 1954, Tether mentioned that pyridostigmine was given to six MG patients in 1947 and reflected on the treatment response of this "pioneering trial"7: "The results were equivocal with the exception that there were fewer reactions than those for neostigmine. In retrospect, our findings at that time were probably due to the low dosage used (30 mg)."

In the same year (1954), Schwab and Timberlake stated that pyridostigmine was given to $10 \mathrm{MG}$ patients in $1948^{5}$. The authors highlight the results of pyridostigmine comparing to those of neostigmine therapy5: "We found no such increase in the duration of the effect, and the drug was not considered as effective in myasthenia gravis as the parent compound in the doses used." Thus, pyridostigmine was not considered as effective as therapy in MG patients in this pioneering trial as well ${ }^{5}$. Compared to neostigmine, the benefit was only related to drug tolerability5: "We did note that it had no unfavorable effect on the gastrointestinal tract." Additionally, three patients also used intramuscular pyridostigmine with similar results at the dosages of 4, 5 and $6 \mathrm{mg}^{5}$.

In the mentioned trials, pyridostigmine was tried in an oral dosage, that was comparable to that of neostigmine, shortly after it became available ${ }^{5,7}$. Both "pioneering trials" failed to prove a beneficial response to pyridostigmine in $\mathrm{MG}$ therapy ${ }^{5,7}$. However, in the 1950s, these authors began to reassess pyridostigmine, using large individual doses ${ }^{5,7}$. In their retrospective analysis, they believed that the low dosage used in the "pioneering trials" was responsible for the equivocal results ${ }^{5,7}$. Maybe, we could speculate that these poor results were a reason for demotivating the authors to publish their results on pyridostigmine therapy earlier.

Indeed, cases of effective response were reported in $\mathrm{MG}$ patients in the following years, also using other dosages of pyridostigmine with a beneficial response ${ }^{12}$. Almost simultaneously, general detailed reports as to the chemical and pharmacologic data had been published based on experimental studies ${ }^{3-8}$.

The retrospective analysis of the "pioneering trials", as well as the results of experimental studies, motivate neurologists to treat MG patients with different doses of pyridostigmine $^{5}$. In 1953, preliminary reports of four MG series revealed beneficial responses with pyridostigmine therapy in Europe (Table 1) ) $^{3-14}$. The consensus by these investigators is
Table 1. The "historical trials" of pyridostigmine bromide in the treatment of myasthenia gravis.

\begin{tabular}{|c|c|c|}
\hline $\begin{array}{l}\text { Author, year } \\
\text { (Original } \\
\text { Language }{ }^{\#} \text { ) }\end{array}$ & (n) \#\# & Outcome \\
\hline $\begin{array}{l}\text { Tether, } 1947^{7} \\
\text { (English) }\end{array}$ & 6 & $\begin{array}{l}\text { The "results were equivocal" } \\
\text { with the exception that there } \\
\text { were fewer reactions than with } \\
\text { neostigmine. However, a low dosage } \\
\text { of pyridostigmine was used (30 mg). } \\
\text { This "trial" was only cited in } 1954 \text {. }\end{array}$ \\
\hline
\end{tabular}

\begin{tabular}{|c|c|c|}
\hline $\begin{array}{l}\text { Schwab et al., } \\
1948^{5} \\
\text { (English) }\end{array}$ & 10 & $\begin{array}{l}\text { No better than neostigmine. No } \\
\text { unfavorable adverse event. The } \\
\text { pyridostigmine dosage was the } \\
\text { same of the neostigmine. This "trial" } \\
\text { was only cited in } 1954 . .^{5}\end{array}$ \\
\hline
\end{tabular}

Pyridostigmine had advantages over a previous treatment with neostigmine: first and foremost, it Welte, $1953^{14} \quad 5$ was more effective and tolerated (German) 5 with no side effects, especially in high doses; and, second, also had a prolonged duration of its effect with physical rest.

\begin{tabular}{|c|c|c|}
\hline $\begin{array}{l}\text { Seibert, } \\
1953^{10} \\
\text { (German) }\end{array}$ & 23 & $\begin{array}{l}\text { Favorable experience. The effect is } \\
\text { more intense and lasts longer. Side } \\
\text { effects only occur rarely on and } \\
\text { keep within tolerable limits. Therapy } \\
\text { started in } 1948 \text { for some patients. }\end{array}$ \\
\hline $\begin{array}{l}\text { Bauer et al., } \\
1953^{3} \\
\text { (German) }\end{array}$ & 5 & $\begin{array}{l}\text { The longest duration of the action } \\
\text { offered one advantage over } \\
\text { neostigmine. The good tolerability } \\
\text { of the drug allowed an increase in } \\
\text { the required amount without the } \\
\text { threat of side effects. Experimental } \\
\text { pharmacological tests, comparing } \\
\text { neostigmine and pyridostigmine, on } \\
\text { the phrenic diaphragmatic nerve and } \\
\text { on the masticatory muscles of the rat } \\
\text { supplemented clinical observations. }\end{array}$ \\
\hline
\end{tabular}

\begin{tabular}{|c|c|c|}
\hline $\begin{array}{l}\text { Struppler, } \\
1953^{11} \\
\text { (German) }\end{array}$ & 20 & $\begin{array}{l}\text { The effects of pyridostigmine were } \\
\text { indicated by examples (reported } \\
\text { in few patients) based on clinical } \\
\text { and experimental observations. } \\
\text { Pyridostigmine was enough to make } \\
\text { the patient adequately treated, but } \\
\text { the optimal effect was reached only } \\
\text { after about } 1 \text { hour (greater latency } \\
\text { than for neostigmine). }\end{array}$ \\
\hline $\begin{array}{l}\text { Schwab et al., } \\
1954^{5} \\
\text { (English) }\end{array}$ & 50 & $\begin{array}{l}20 \text { patients found the drug } \\
\text { superior to neostigmine. "Large" } \\
\text { individual doses were used. } \\
\text { The "antimyasthenic effect" was } \\
\text { calculated as one fourth of the } \\
\text { equivalent amount of neostigmine. }\end{array}$ \\
\hline $\begin{array}{l}\text { Osserman } \\
\text { et al., } 1954^{6} \\
\text { (English) }\end{array}$ & 20 & $\begin{array}{l}15 \text { patients found pyridostigmine } \\
\text { more effective than neostigmine. } \\
\text { Side-reactions were absent or so } \\
\text { diminished that the use of atropine } \\
\text { could be stopped. }\end{array}$ \\
\hline
\end{tabular}

Continue... 
Table 1. Continuation.

\begin{tabular}{|c|c|c|}
\hline $\begin{array}{l}\text { Author, year } \\
\text { (Original } \\
\text { Language }^{\#} \text { ) }\end{array}$ & (n) \#\# & Outcome \\
\hline $\begin{array}{l}\text { Westberg et } \\
\text { al., } 1954^{8} \\
\text { (English) }\end{array}$ & 22 & $\begin{array}{l}21 \text { patients preferred pyridostigmine } \\
\text { over neostigmine. The duration and } \\
\text { maintenance of effect was longer. } \\
\text { Side effects were mild. }\end{array}$ \\
\hline $\begin{array}{l}\text { Tether, } 1954^{7} \\
\text { (English) }\end{array}$ & 56 & $\begin{array}{l}\text { Neostigmine and pyridostigmine } \\
\text { provided relatively equal control } \\
\text { of "myasthenic symptoms." } \\
\text { Pyridostigmine provides smoother } \\
\text { and a more sustained control of } \\
\text { symptoms. Untoward reactions } \\
\text { are less frequent and less } \\
\text { intense. No toxicity was noted. } \\
\text { Pyridostigmine was less desirable } \\
\text { than neostigmine, because it has a } \\
\text { slower onset of action. }\end{array}$ \\
\hline
\end{tabular}

\#: from publication; \#\#: number of patients treated with pyridostigmine bromide.

that pyridostigmine was superior, or equivalent, to neostigmine ${ }^{3-14}$. In 1954, other four preliminary trials from the United States helped to establish that four-times-higher doses of pyridostigmine produced a more even response with less toxicity and was subjectively better tolerated by most MG patients (Table 1$)^{5-9}$. In some patients, pyridostigmine bromide was also tested by intravenously or intramuscularly administration $^{6}$. The pyridostigmine bromide used in these studies was supplied by Hoffman-La Roche ${ }^{6,7}$.
These preliminary trials are briefly summarized in the Table $1^{3-14}$. In the trials, pyridostigmine was usually compared to neostigmine, which was the "gold standard" of the anticholinesterase agents in MG therapy, at that time $\mathrm{e}^{3-14}$. Most patients reported that pyridostigmine give them similar or better strength than neostigmine ${ }^{3-14}$. However, pyridostigmine takes effect in a shorter time, has a longer effect and causes lesser undesirable adverse events than neostigmine ${ }^{3-14}$.

After 70 years of pyridostigmine therapy, several articles recognized that the unsuccessful results in the "pioneering trials" were probably caused because pyridostigmine was tried at the same milligram dosage as neostigmine $e^{5,9}$. After these, other trials confirm its beneficial response and pyridostigmine bromide was approved as an MG therapy. Thus, pyridostigmine has become the drug of choice in the treatment of MG since $1954^{2}$. Currently, pyridostigmine has been cited associated to the therapy in MG patients in more than 8,000 articles in Google Scholar database (Dec 2018), since the "pioneering trials" in the late 1940s. In addition, the term [pyridostigmine, myasthenia gravis] can be identified in more than 800 articles in the PubMed database (Dec 2018).

\section{ACKNOWLEDGEMENTS}

We would like to thank "Novartis's Information Search Program" (informec), which provided some of the original articles cited in the references.

\section{References}

1. Carvalho VM, Nogueira EAG, Rosa GR, Fragoso YD. Mary Broadfoot Walker: 83 years since a historical discovery. Arq Neuropsiquiatr. 2017 Nov;75(11):825-26. http://dx.doi.org/10.1590/0004$282 \times 20170138$

2. Cunha FMB, Scola RH, Werneck LC. Myasthenia gravis: historical aspects. Arq Neuropsiquiatr. 1999 Jun;57(2B):531-6. http://dx.doi. org/10.1590/S0004-282X1999000300030

3. Bauer H, Schmid O.Zur medikamentösen Behandlung der Myasthenie. Dtsch Z Nervenheilkd. 1953;169(6):427-37.

4. Maggi L, Mantegazza R. Treatment of myasthenia gravis: focus on pyridostigmine. Clin Drug Investig. 2011 Oct;31(10):691-701. https:// doi.org/10.2165/11593300-000000000-00000

5. Schwab RS, Timberlake WH. Pyridostigmin (Mestinon) in the treatment of myasthenia gravis. N Engl J Med. 1954 Aug;251(7):2712. https://doi.org/10.1056/NEJM195408122510706

6. Osserman KE, Teng P, Kaplan LI. Studies in myasthenia gravis: preliminary report on therapy with mestinon bromide. JAMA. 1954 Jul;155(11):961-5. https://doi.org/10.1001/ jama.1954.03690290011004
7. Tether JE. Mestinon in myasthenia gravis (preliminary report). Dis Nerv Syst. 1954;15(8):227-31.

8. Westberg MR, Magee KR. Mestinon in the treatment of myasthenia gravis. Neurology. 1954 Oct;4(10):762-71. https://doi.org/10.1212/WNL.4.10.762

9. Keesey JC. A history of treatments for Myasthenia Gravis. Semin Neurol. 2004 Mar;24(1):5-16. https://doi.org/10.1055/s-2004-829584

10. Seibert von P.Zur Behandlung der Myasthenia gravis: Klinische Erfahrungen über die Behandlung der Myasthenia gravis pseudoparalytica mit Pyridostigmin. Dtsch Med Wochenschr. 1953;22:805-7.

11. Struppler A. Further progress in therapy of myasthenic syndrome. Med Monatsschr. 1953;7(7):428-32.

12. Sutter JM, Jorda M, Lebascle J. A case of Erb-Goldflam myasthenia. Trial of a new anti-myasthenic product. Rev Otoneuroophtalmol. 1953 Mar;25(3):169-72.

13. Seibert P. Treatment of myasthenia gravis: clinical experiences concerning treatment of pseudoparalytic myasthenia gravis with Pyridostigmine (abstract). JAMA. 1953;153:75.

14. Welte E. Myasthenia gravis pseudoparalytica. Fortschr Neurol Psychiat. 1953;21:57 